\title{
Adipose tissue as mesenchymal stem cells source in equine tendinitis treatment
}

\author{
Tecido adiposo como fonte de células tronco mesenquimais no \\ tratamento da tendinite equina
}

\author{
Armando de Mattos Carvalho ${ }^{1 *}$; Carlos Alberto Hussni²; Ana Liz Garcia Alves ${ }^{2}$
}

\begin{abstract}
Tendinitis is an important high-relapse-rate disease, which compromises equine performance and may result in early athletic life end to affected animals. Many therapies have been set to treat equine tendinitis; however, just few result in improved relapse rates, quality of extracellular matrix (ECM) and increased biomechanical resistance of the treated tissue. Due to advances in the regenerative medicine, promising results were initially obtained through the implantation of mesenchymal stem cells (MSC) derived from the bone marrow in the equine tendon injury. Since then, many studies have been using MSCs from different sources for therapeutic means in equine. The adipose tissue has appeared as feasible MSC source. There are promising results involving equine tendinitis therapy using mesenchymal stem cells from adipose tissue (AdMSCs).
\end{abstract}

Keywords: Tendon. Therapy. Stem cells. Regenerative medicine.

\section{Resumo}

A tendinite é uma importante afecção com alta taxa de recidivas que compromete o desempenho de equinos e pode resultar no término precoce da vida atlética dos animais acometidos. Diversas terapias têm sido estabelecidas para o tratamento da tendinite equina, no entanto poucas resultam na melhora da taxa de recidiva, melhora da qualidade da matriz extracelular (MEC) e aumento da resistência biomecânica do tecido tratado. Com o advento da medicina regenerativa resultados promissores foram inicialmente obtidos com o implante de células tronco mesenquimais (CTMs) derivadas da medula óssea na lesão tendínea de equinos. Desde então, diversos estudos têm sido conduzidos utilizando CTMs de diferentes fontes para esta finalidade terapêutica em equinos. $\mathrm{O}$ tecido adiposo tem se mostrado como uma fonte viável de CTMs e também há resultados promissores envolvendo a terapia da tendinite equina utilizando as células tronco mesenquimais derivadas do tecido adiposo (AdCTMs). Neste artigo, dados relacionados ao uso das AdCTMs na terapia da tendinite equina serão revisados.

Palavras-chave: Tendão. Terapia. Células tronco. Medicina regenerativa.

\footnotetext{
${ }^{1}$ Prof. Dr., Biociência Animal, Universidade de Cuiabá, UNIC, Cuiabá, MT, Prof. Dr. Adjunto, Departamento de Clínica e Cirurgia Veterinárias, Universidade Federal de Minas Gerais, UFMG, Belo Horizonte, MG, Brasil. E-mail: armandodvm@gmail.com

2 Prof $^{\mathrm{s}}$ Dr $^{\mathrm{a}_{\mathrm{s}}}$ Adjunto, Departamento de Cirurgia e Anestesiologia Veterinária, Universidade Estadual Paulista, UNESP, Botucatu, SP, Brasil. E-mail: cahussni@fmvz.unesp.br; anaalves@fmvz.unesp.br

* Author for correspondence
} 


\section{Introduction}

The tendon connects the bone to the muscle. It is essential to convey the strength, which produces the movement in the joints. The tendon injury leads to the lameness and decreased performance of athlete horses. There are studies indicating that tendinitis is the main injury in soft tissues and that it may result in the early end of the career of thoroughbred racehorses (KASASHIMA et al., 2004).

The tendon injury often requires a considerable rest period (from six months up to one year) in order to enable tissue repair. The conventional treatment options for tendinitis are basically clinical and surgical; however, the animals hardly present healing quality good enough to allow their return to competitions with the same performance they had before the injury (MARFE et al., 2012). It is common belief that the tendon is prone to inefficient healing due to the tendinous structure, which is little vascularized, relatively acellular and has limited regeneration potential (YOUNG, 2012). It is also worth highlighting the importance of type I collagen, which is the most abundant one in the healthy tendon (approximately 95\% of the total collagen) and responsible for strength and elasticity. The type III collagen is synthesized during tendinous healing and it results in the higher percentage of it (20-30\%) in the injured tendon than in the healthy one $(1 \%)$, thus leading to the formation of biomechanically inferior scar tissue, fact that increases the chance of relapses (MCCULLAGH et al., 1979; WILLIAMS et al., 1980).

The regenerative medicine is defined as an innovative medical therapy that favors the repair, replacement, restoration and regeneration of damages and diseases of cells, tissues and organs (SPAAS et al., 2012). It offers the perspective of restoring the structure and function of the compromised tendon, thus taking the tendon back to normal or to almost normal and enabling the restoration of its activity with lower relapse risk (BUTLER et al., 2008).
The biotechnology has been leading the significant evolution of the regenerative medicine. There are promising studies about the use of cellular therapy to treat equine tendinitis. Clinical study results, for instance, have shown significant reduction in tendinitis relapse rates after at least two-year follow up applied to animals treated with cellular therapy in comparison to those treated with conventional therapies; their relapse rate was 27\% and 56\%, respectively (GODWIN et al., 2012).

The option for the cellular therapy to treat equine tendinitis was initially reported through the use of mesenchymal stem cells (MSCs) from the bone marrow in tendon injuries of the superficial digital flexor tendon (SDFT) (SMITH et al., 2003). Since then, many studies have been conducted using MSCs from different sources to treat equine tendinitis such as from the bone marrow (SMITH et al., 2013), the adipose tissue (NIXON et al., 2008), the peripheral blood (MARFE et al., 2012), the umbilical cord blood (VAN LOON et al., 2014) and from the amniotic membrane (LANGE-CONSIGLIO et al., 2012).

So far, the MSCs from the bone marrow have been the most studied ones; they have been used in equine tendinitis therapy. Thus, there is more knowledge about the differentiation potential of these cells, as well as more evidences about the improvement in experimental clinical cases involving the equine tendinitis therapy (WATTS, 2014). The adipose tissue is another important source, which stands out in equine tendinitis therapy (MUTTINI et al., 2012; REED; LEAHY, 2013). Recent studies show the tenogenic differentiation potential of mesenchymal stem cells from adipose tissue (AdMSCs), and they evidence the therapeutic potential of this source for equine tendinitis treatment (RAABE et al., 2013).

The first study about the assessment of experimental tendon repair using adipose tissue as cellular therapy source was conducted by Nixon et al. (2008). However, the stromal vascular fraction (SVF) replaced the AdMSCs that were isolated and 
cultivated in the laboratory. The main results in the current study were the improved organization of treated tendons and the increased gene expression of cartilage oligomeric matrix protein (COMP). Other studies using AdMSCs to treat equine tendinitis were also conducted; they led to promising results (DEL BUE et al., 2008; CARVALHO et al., 2011, 2013a, 2014a; RICCO et al., 2013).

Many forms of equine tendinitis therapy are already available in the market, although they were not completely assessed for their real effectiveness and safety, due to the pressure performed by the marketing business (NIXON et al., 2012). The absence of a specific review about the information on the use of AdMSCs in equine tendinitis therapy was also noticed. Thus, the aim of the current review is to focus on different methodologies regarding the use of AdMSCs, on experimental studies, as well as on the challenges that have to be overcome in order to get tendinous regeneration.

\section{The reasons for using AdMSCs in equine tendinitis} treatment

The tendon is prone to injuries and its intrinsic hypocellularity and hypovascularization make its natural healing slow and inefficient when the tendon is severely damaged. Its limited self-repair skill along with the limitation of effective treatments have encouraged the development of therapies based on the use of stem cells to explore the natural endogenous system of tissue regeneration (GONÇALVES et al., 2013).

Among all the equine orthopedic diseases treated through cellular therapy, tendinitis is the one with stronger evidences of tissue regeneration and clinical improvement. Although it was also possible noticing histopathological and biomechanical improvement, the greatest and most tangible result seems to be the remarkable decrease in the relapse rate (WATTS, 2014). A recent clinical study followed - for more than two years
- the relapse rate in animals with tendinitis treated with MSCs from bone marrow and in animals that have received conventional treatment. The group treated with cellular therapy presented relapse rate of approximately $27 \%$, whereas the group treated with the conventional treatment presented relapse rate between 56\% and 58\% (GODWIN et al., 2012).

The injuries in the SDFT are the cause of many additional elements necessary to the tissue engineering. The injuries often manifest in the central region of the tissue and build a natural sheath to the implantation, which - by the implantation time of the stem cells - is filled with granulation tissue, which works as a supporting structure. The tendon injuries have the advantage of being highly vascularized and, consequently, they are able to give nutritional support to the implanted progenitor cells (ALVES et al., 2011). These features turn the equine SDFT injuries into an appropriate site to the implantation of MSCs, since they provide the necessary support to the action of these cells in tissue repair modulation.

Another feature that has drawn even more attention to equine tendinitis studies is the pathogenesis and the histopathology resemblance between the equine SDFT injuries and the tendinopathy of the human Achilles tendon (LUI et al., 2011). Thus, studies about the therapy using MSCs in natural-occurrence injuries in equines may work as the basis of experimental models to the clinical application of MSCs in humans (SPAAS et al., 2012).

\section{The action mechanism of MSCS}

The action mechanisms of MSCs used to promote tissue repair have been better understood with time. At first, there was the belief that tissue repair was obtained through the in vivo differentiation of the MSCs implanted to the prevailing cellular type in the tissue, i.e., when 
the MSCs were implanted in the tendon they would become cells similar to the tenocytes, thus favoring the synthesis of extracellular matrix (ECM) components and establishing the tissue repair. However, so far, it is known that the MSCs have tenogenic differentiation potential in vitro (RAABE et al., 2013). Evidences that the implanted MSCs may differentiate from the tendon cells in vivo still lack (CARVALHO et al., 2014b). It is more evident that MSCs may result in expressive tissue repair and promote the reconstruction of the structure and function of the damaged organ without the differentiation or fusion between the implanted cells and the specialized cells of the treated organ (STRIOGA et al., 2012).

Nowadays, it is known that the action mechanism of MSCs is complex and that it takes place through the secretion of bioactive molecules that have regenerative activities such as the secretion of bioactive factors. These bioactive factors are capable of inhibiting the formation of scar tissue, suppressing the apoptosis, stimulating the angiogenesis and improving mitosis in the progenitor cells of the intrinsic tissue. Such "proregenerative" action of the MSCs dues to bioactive molecule actions has been referred to as "trophic activity" (NOTH et al., 2010). There are scientific data confirming that MSCs release many growth factors in the implanted site, among them there are the vascular endothelial growth factor (VEGF), the hepatocyte growth factor (HGF) and the insulin-like growth factor (IGF-1) (WANG et al., 2006).

Equally, there is the description of the immunomodulatory action of the MSCs, since these cells seem to be hypo-immunogenic and perform significant suppression action over the $\mathrm{T}$ and dendritic cells, mainly with regard to the suppression of the allogenic rejection and, in some cases, to the modulation of the immunological system (CAPLAN; DENNIS, 2006). There are therapeutic studies about the equine species using the allogenic implantation (material from other animal) of AdMSCs in the tendon. These studies show that there was no inflammatory reaction in the animals implanted with progenitor cells from other animals (DEL BUE et al., 2008).

Nowadays, the anti-inflammatory action of MSCs stands out among the different action mechanisms of these cells. Although there is no record on how the inflammation modulation intermediated by the implanted MSCs takes place in the tendon, there is the belief that the anti-inflammatory action may favor tissue repair, either through the inhibition of IFN- $\gamma$ and TNF- $\alpha$ or through the stimulation of metalloproteinases inhibitors and of anti-inflammatory interleukins such as the IL-10(CAPLAN, 2009). Recent studies show that the AdMSCs suspended in platelet concentrate were used in the experimental treatment of equine tendinitis two weeks after the induction, and it suggests the possible antiinflammatory action with consequent prevention of injury progression (CARVALHO et al., 2013a). It is believed that the anti-inflammatory action of MSCs is responsively modulated to the tissue injury microenvironment the cells were implanted in (PROCKOP; OH, 2012). Thus, the MSCs must have the adequate response to the injury degree and modulate the local environment in order to reduce the inflammation, the apoptosis and/or to increase the ECM synthesis through the endogenous progenitor cells and through the specific cells of the tissue (WATTS, 2014).

The mesenchymal stem cells from adipose tissue (AdMSCs)

The first report about the isolation of precursor cells from human adipose tissue dates back to 1976 (VAN et al., 1976). However, it was after the isolation and featuring of human AdMSCs conducted by Zuk et al. (2001) that the adipose tissue was acknowledged as an alternative source to the bone marrow in the obtainment of MSCs. 
The most often used area to collect adipose tissue in equine is that atop the dorsal muscle of the gluteus and parallel to the basis of the tail; this collection can be performed in confined animals. This area allows obtaining significant amounts of fat; however, it is possible getting a little bit of fat in case of racehorses with fit athletic body. The animal is sedated to the collection of adipose tissue; the paraxial caudodorsal gluteal region was clipped, as well as the antisepsis. Skin and subcutaneous desensitization is done through blocking in inverse L shape using 2\% lidocaine. An approximately $10 \mathrm{~cm}$ long incision is performed $15 \mathrm{~cm}$ abaxial to the vertebral column in order to expose the adipose tissue between the skin and the musculature. The volume between 5 and $15 \mathrm{~mL}$ of fat may be collected. The skin suture is then performed using nylon suture material (ALVES et al., 2011).

Routinely, the adipose tissue is digested through collagenase or through lytic enzymes in order to release the heterogeneous population called stromal vascular fraction (SVF) or adiposederived mononuclear cells, which consist of a heterogeneous mixture of cells including the endothelial cells, smooth muscle cells, MSCs, fibroblasts, mast cells and preadipocytes (ZUK et al., 2001). The SVF cells can be used right the way or they may be cultivated on plastic plates in order to select and expand the adherent population known as AdMSCs (GIMBLE et al., 2010). Although the expansion of the AdMSCs in the laboratory involves higher costs, more manpower and time interval from two to three weeks to get the desired number of AdMSC, there is the belief that their use is advantageous because their progenitor cells population is more homogeneous and larger than that in the SVF (ALVES et al., 2011). Another information that corroborates the use of AdMSCs is the possibility of transporting them at $4^{\circ} \mathrm{C}$ for up to 24 hours, fact that makes it feasible to use the cells expanded in laboratory to clinical application in the area(MERCATI et al., 2014).
The AdMSCs in equine were initially isolated and featured by Vidal et al. (2007). Since then, many isolation and featuring studies have been conducted (CARVALHO et al., 2009, 2013b; MAMBELLI et al., 2009; BARBERINI et al., 2014). A growing number of studies assessing the impact of stem cells from adipose tissue on large animals have been conducted. However, studies involving equines are hindered by the lack of monoclonal antibodies appropriate to cell tracking and immunophenotypical featuring (GIMBLE et al., 2010). It is crucial featuring the isolated cells in order to prove that they are progenitor cells. Accordingly, a standardization protocol was suggested for the correct featuring of MSCs in equine. The cells must be adherent to plastic within the culture; their adipogenic, chondrogenic and osteogenic differentiation must be set in vitro, under specific differentiation conditions; and these cells must positively express the CD29, CD44 and CD90markers, as well as negatively express the CD14, CD79 and MHC-II markers (DE SCHAUWER et al., 2011).

What is the best source to be used, adipose tissue or bone marrow?

Most studies about equine tendinitis therapy involve MSCs from bone marrow; thus, it is inevitable comparing these cells to the AdMSCs. Truth is that, at this very moment, there are no data enough to allow comparing these two MSCs sources in order to point out the most adequate of them to the cellular therapy against equine tendon injuries. However, some features of the adipose tissue make its use more feasible than the clinical application of MSCs from bone marrow. Some examples of it are the easiness of collecting fat tissue from the base of the equine's tail, since it does not demand the previous training or expertise of the veterinarian who will proceed with it. On the other hand, the bone marrow puncture in equines may be conducted in the fifth sternebrae or in the 
coxal tuberosity (ilium). Therefore, it is necessary using specific needles and having properly trained vets. There is a report about pneumopericardium after the puncture in the sternal region (DURANDO et al., 2006). The SVF of the adipose tissue has higher MSC concentration than the mononuclear bone marrow cells; thus, it is more interesting using the SVF when MSCs are not isolated and expanded in the laboratory (STRIOGA et al., 2012; ALVES et al., 2013).

There are also recent studies with equines that compare the expression of the main proteins in the extracellular tendinous matrix between the different MCS sources (bone marrow, adipose tissue, umbilical cord tissue, umbilical cord blood, tendinous tissue). The AdMSCs were those with greater type I and III collagen and decorin expression. Once the improvement in the cellular matrix has been pointed as the main beneficial effect of the cellular therapy against tendinitis, the use of adipose tissue as stem cell source may result in therapeutic effect better than that of other sources, since it has greater protein expressions such as type I collagen (BURK et al., 2014).

Data about human AdMSCs show that they are genetically and morphologically stable in long-term culture, have lower senescence rate and greater proliferation capacity, keep the differentiation potential for longer in the culture than the MSCs from bone marrow (IZADPANAH et al., 2006). However, these data were not assessed for equine cells.

At first, there was the belief that the MSCs from bone marrow had greater AdMSCs differentiation potential in equines (VIDAL et al., 2007). However, recent studies have shown that the differentiation potential of bone marrow progenitor cells and of the adipose tissue is similar (BARBERINI et al., 2014), and that the initially observed differences would due to lack of adjustments in the differentiation inducer medium necessary to the AdMSCs (STRIOGA et al., 2012). It is also worth highlighting that there are no studies comparing the therapeutic effects of MSCs from different sources (adipose tissue $\mathrm{x}$ bone marrow) used in equine tendinitis therapy; thus, it is necessary to conduct further investigations about it, since there are signs that the adequate source selection may broaden the effects of the cellular therapy (GARVICAN et al., 2014).

\section{SVF and AdMSCs in the equine tendinitis treatment}

The cellular therapy against equine tendinitis using progenitor cells from adipose tissue is based on the administration of SVF or AdMSCs. Most studies, so far conducted, are based on the tendinitis treatment experimentally induced by collagenase; when the study is related to natural-occurrence tendinitis therapy, such information will be shown in Table 1.

The first study using stem cells from equine adipose tissue to treat equine tendinitis used the autologous SVF suspended in PBS in the treated group, and PBS in the control group, to treat injuries in the SDF muscle. Weekly ultrasound assessments up to the sixth week, followed by the animal's euthanasia and by histopathological, biochemical and molecular analyses were performed. There was improvement in the collagen fibers, vascularization reduction, inflammatory and type III collagen fiber infiltrate. The gene expression assessment showed increased cartilage oligomeric matrix protein (COMP) in the treated tendons (NIXON et al., 2008). From this study on, other researchers used AdMSCs (CARVALHO et al., 2011, 2014a, 2014b), or AdMSCs in combination with platelet concentrate $(\mathrm{PC})$ in equine tendinitis therapies (DEL BUE et al., 2008; CARVALHO et al., 2013a; RICCO et al., 2013; GUERCIO et al., 2015). 
Table 1. The chronological order of studies using mesenchymal stem cells from adipose tissue in equine tendinitis therapy.

\begin{tabular}{|c|c|c|c|c|}
\hline Therapy & Suspension & SDFT Lesion & Results & Reference \\
\hline SVF & PBS & Collagenase induced & $\begin{array}{l}\text { Histopathological improvement } \\
\text { Type III collagen decrease } \\
\text { COMP increase }\end{array}$ & (NIXON et al., 2008) \\
\hline AdMSCs & PC & Natural occurrence & $87.5 \%$ returned to the sport & (DEL BUE et al., 2008) \\
\hline AdMSCs & Serum & Collagenase induced & $\begin{array}{l}\text { Histopathological improvement } \\
\text { Type I collagen increase }\end{array}$ & (CARVALHO et al., 2011) \\
\hline AdMSCs & PC & Natural occurrence & $89.5 \%$ return to the sport & (RICCO et al., 2013) \\
\hline AdMSCs & $\mathrm{PC}$ & Collagenase induced & $\begin{array}{l}\text { Improved histopathology } \\
\text { Improved ultrasound }\end{array}$ & (CARVALHO et al., 2013a) \\
\hline AdMSCs & Serum & Collagenase induced & Increased vascularization & (CARVALHO et al., 2014a) \\
\hline AdMSCs & DMEM & Collagenase induced & Viability of the AdMSCs in vivo & (CARVALHO et al., 2014b) \\
\hline AdMSCs & $\mathrm{PC}$ & Natural occurrence & Improved ultrasound & (GUERCIO et al., 2015) \\
\hline
\end{tabular}

SDFT: superficial digital flexor tendon, SVF: stromal vascular fraction, PBS: phosphate buffered saline, COMP: cartilage oligomeric matrix protein, AdMSCs: mesenchymal stem cells from adipose tissue, PC: platelet concentrate, DMEM: Dulbecco's modified eagle's medium.

The best medium for MSCs suspension at therapy time remains unknown. Some studies use the supernatant of the bone marrow or the PC for the suspension of MSCs from bone marrow (SCHNABEL et al., 2013). There is the belief that the bone marrow supernatant has beneficial effect when it is used along with the progenitor cells (SMITH; WEBBON, 2005). Something similar is done with the AdMSCs suspended in PC, which, after its activation, promotes the formation of a supporting structure so that the injected progenitor cells remain accommodated, as well as promotes the production of growth factors that may also help tissue repair (DEL BUE et al., 2008). It is worth highlighting that $\mathrm{PC}$ is an easily-obtained biological autologous product gotten through total blood platelet concentration; its processing is fast and demands low costs (TEXTOR; TABLIN, 2012). Just as the promising cited results about the use of AdMSCs, there are also studies showing favorable results about the use of $\mathrm{PC}$ in equine tendinitis therapies such as better ultrasound evaluations (ARGUELLES et al., 2008), increased local vascularization (BOSCH et al., 2010).
The first study associating the therapeutic use of autologous PC and allogenic AdMSCs to treat natural-occurrence tendinitis was conducted by Del Bue et al. (2008). The use of allogenic progenitor cells was justified by the availability of frozen cells, which were well featured through their differentiation and proliferation potential; through the possibility of having an early treatment, without the need of waiting for the isolation, featuring and expansion necessary to the use of autologous cells; through the no need of collecting adipose tissue from the treated horse; through the possibility of using a number of cells adequate to the injury size. Among the 16 treated animals in the aforementioned study, 14 recovered and returned to the athletic activity. There was a report about moderate local swelling and sensitivity in $50 \%$ of the animals; according to these authors, it was caused by intralesional administration. However, there was no assessment about a possible inflammatory reaction to the implanted allogenic AdMSCs. Ricco et al. (2013) associated allogenic AdMSCs and autologous PC to treat natural-occurrence tendinitis, before 20-days evolution. Clinical and ultrasound enhancement 
was noticed in the treated animals after six months; after 24 months of therapy, $11 \%$ of the treated animals had a relapse. The study also showed no inflammatory reaction to the allogenic cells used in the therapy. Although the number of animals used in their study was smaller than 19 animals, in comparison to other previous study that has used MSCs from bone marrow to treat equine tendinitis in 113 animals with $27.4 \%$ relapse (GODWIN et al., 2012), these data depict repair improvement in the tendon treated with cellular therapy, regardless of the used source of MSCs.

Although equine MSCs are considered immune-privileged (DE SCHAUWER et al., 2014), the use of allogenic cells in the therapy remains controversial (WATTS, 2014). Even with the non-confirmation of differences regarding the immediate immunological cellular reaction against the autologous or allogenic MSCs after the therapy against the SDF tendinitis in equine (GUEST et al., 2008), this subject still requires major clarifications. A recent study showed heterogeneous expression of the main complex of class II histocompatibility (MHC class II) of the MSCs from bone marrow, as well as showed that the positive MHC class II MSCs are able to trigger an immunological reaction in vitro. Thus, it is recommended that the potential MSCs donors for future allogenic applications are negative MHC class II (SCHNABEL et al., 2014). However, this study also reported that even the negative MHC class II MSCs have the potential to increase the MHC class II expression when they are implanted in an active inflammation area. It was demonstrated in vitro through the stimulation of the negative MHC class II MSCs by using INFand these MSCs started expressing MHC class II (SCHNABEL et al., 2014). Thus, the need of additional studies regarding the administration of allogenic MSCs becomes evident, mainly in cases of repeated applications or in active inflammation areas (LOPEZ; JARAZO, 2015)'.

The development of new studies related to the implantation of allogenic progenitor cells is substantiated by the benefits from this therapy type such as the reduced variability between treatments, different cultures among patients with different features (age), the reduced time between diagnosing and treating, and the possible increased therapeutic effectiveness when using cells from young individuals (donors) in old patients (WATTS, 2014). It is known that the osteogenic differentiation potential of adult women AdMSCs decreases with aging (CONZE et al., 2014), and, in equine, there was great variation in the differentiation and proliferation potential of mare AdMSCs in the age group 10-13 years (CARTER-ARNOLD et al., 2014). Therefore, the allogenic implantation of mesenchymal stem cells would favor the "standardization" of the cellular therapy; just the AdMSCs of young animals with proved viability, proliferation and differentiation potential would be selected.

Another relevant factor to be considered is the moment for the cellular therapy. At first, it was recommended to treat the tendon after the inflammatory phase and before the formation of fibrosis, i.e., during the proliferative phase, between 10 and 45 days after the emergence of the injury (FORTIER; SMITH, 2008). However, based on the anti-inflammatory effects and on the ability of stem cells to modulate tissue repair and to regenerate through endogenous cellular recruiting and trophic factors production, the early therapy may be advantageous (SCHNABEL et al., 2013; WATTS, 2014). By taking into consideration the time needed to isolate and expand the AdMSCs (2 weeks), it would be impossible instituting the therapy using autologous progenitor cells in the initial phase; therefore, it would be more important using the allogenic AdMSCs. Even if further studies prove the safety and efficiency of using allogenic AdMSCs before the implantation of the commercial therapy in equine medicine, it will be necessary adopting a standard operational procedure in all laboratories in order to regulate the cellular isolation, cultivation and featuring practices. The content must also be 
assessed in order to find the presence of aerobic and anaerobic bacteria, endotoxins, mycoplasma and viruses (GIMBLE et al., 2010).

A recent study used the implantation of autologous AdMSCs combined with autologous PC in natural-occurrence equine tendinitis therapy in athlete animals (GUERCIO et al., 2015). The study showed recovered tendon injury in the ultrasound, as well as the complete return to the physical activities in seven of the nine treated animals. The authors justify the inadequate rehabilitation period necessary to the complete tendon repair as the cause of relapse in one of the experiments. Another study combined PC and autologous AdMSCs in experimental equine tendinitis therapy after 14 days of injury induction (CARVALHO et al., 2013a). Similar to previous studies, the histopathological improvement became evident either due to the diminished inflammatory infiltrate or to the better organization of the collagen fibers. The non-progression of the collagenaseinduced injury was also noticed by means of ultrasound comparison between the treated and the control groups (CARVALHO et al., 2013a). It is an interesting result, because there is evidence that the treatment using the early cellular therapy may avoid injury progression and help treating the pre-existing injuries. The possible explanation for such action would be that the early implantation could offer more benefits to the tendon repair, by reducing inflammation, recruiting native stem cells, and stimulating collagen production, as well as the production of other MSCs (REED; LEAHY, 2013; WATTS, 2014).

Among the studies using AdMSCs to treat tendinitis, one has described intralesional administration guided by ultrasound at $10 \times 10^{6}$ AdMSCs after 30 days of tendon injury induction. Improved collagen fiber organization was observed, as well as lower inflammatory cell deposition and greater type I collagen expression in the immunohistochemical analysis of the treated tendons in comparison to the non-treated ones (CARVALHO et al., 2011). Such result is interesting, because the synthesis of type I collagen during healing is a crucial stage to increase the tendon strength (UYSAL et al., 2012). It could justify the lower relapse rate in equine treated with AdMSCs (RICCO et al., 2013). There is also a report about the increased tendon vascularization induced through AdMSCs therapy by means of histopathological analysis and ultrasound evaluation, using the power Doppler mode and the color Doppler (CONZE et al., 2014; CARVALHO et al., 2014a). Other study using AdMSCs suspended in PC also showed increased tendon vascularization through power Doppler analysis after six weeks of therapy (CARVALHO et al., 2013a). Such increased tendon vascularization may favor tissue repair, since poor vascularization is one of the explanations for the slow tendon repair and for the formation of a biomechanically inferior MSC (GONÇALVES et al., 2013; BURK, 2014).

There is little knowledge about the migration capacity and viability of MSCs injected in the tendon injury. A recent study induced a tendon injury in the SDFT of both forelimbs and, after the administration of marked intralesional AdMSCs in the treated injuries, it assessed the possibility of migrating these cells to the non-treated tendon lesion. The migration of marked AdMSCs to the control tendon was not observed; however, there were marked cells in the blood stream and in the treated tendon after seven days of their administration. It proved the viability of part of the implanted AdMSCs and their capacity to be distributed through the organism via blood stream (CARVALHO et al., 2014b). This result meets that in previous studies, which have used MSCs from the bone marrow marked with technetium ${ }^{99 m}$ to intralesional administration in the SDFT. The presence of marked cells in the implantation area was observed, as well as their presence in organs such as the lung (BECERRA et al., 2013).

The analysis of data described in clinical studies about AdMSCs cellular therapy to treat naturaloccurrence tendinitis shows clinical improvement in the animals, since they return to the physical 
activities and present lower tendinitis relapse rates. These results, along with the results of studies about experimental tendinitis, proved the beneficial effects of the therapy with progenitor cells from adipose tissue, mainly based on morphological analysis (NIXON et al., 2008; CARVALHO et al., 2011, 2013a). Although there was increased interest in using AdMSCs in equine tendinitis therapy, studies about the biomechanical assessment of tendons after the AdMSCs therapy in equines are still scarce. There is, for instance, a report about the increased resistance of rat tendons treated with AdMSCs suspended in PC (UYSAL et al., 2012), and there are no other similar studies that prove the action of AdMSCs in equines.

\section{Final Considerations}

The results of studies related to the use of progenitor cells from adipose tissue in equine tendinitis therapy are promising and justify the development of new studies aiming at enhancing the clinical improvement or even at setting the tendon regeneration. Another explanation lies on the equine flexor tendons, which have pathogenesis and histopathology similar to the tendinopathy of the Achilles tendon in humans. Thus, data from studies about equines may work as the basis to encourage the use of cellular therapy in humans (SMITH et al., 2013).

The advancement of the regenerative medicine applied to the equine species has demonstrated that the adipose tissue really is a feasible alternative source of MSCs to equine tendinitis therapy. It is worth highlighting that the knowledge about the application of MSCs and AdMSCs remains in initial stage and the results obtained through the clinical applications have been promising. However, detailed information about the dose to be administered, about the therapeutic benefit in using the AdMSCs expanded in vitro compared to the SVF, about the indication for the repeated administration of the cellular therapy, about the best solution for cell suspension, about the advantages of the early therapy, as well as about the safety in implanting the allogenic cells still lack. The continuity of welldetailed experimental and clinical studies, besides the use of standardized methods to the isolation, expansion and featuring of the used AdMSCs, may optimize the results of the equine tendinitis therapy and contribute to the evolution of the tendinopathy therapies applied to humans.

\section{References}

ALVES, A. L. G.; CARVALHO, A. M.; HUSSNI, C. Mesenchymal stem cell therapy for equine tendinitis. Recent Patents on Regenerative Medicine, Beijing, v. 3, n. 2, p. 103-110, 2013.

ALVES, A. L. G.; STEWART, A. A.; DUDHIA, J.; KASASHIMA, Y.; GOODSHIP, A. E.; SMITH, R. K. W. Cell-based Therapies for Tendon and Ligament Injuries. Veterinary Clinics of North America: Equine Practice, Fort Collins, v. 27, n. 2, p. 315-333, 2011.

ARGUELLES, D.; CARMONA, J. U.; CLIMENT, F.; MUNOZ, E.; PRADES, M. Autologous platelet concentrates as a treatment for musculoskeletal lesions in five horses. Veterinary Record, London, v. 162, n. 7, p. 208-211, 2008.

BARBERINI, D. J.; FREITAS, N. P.; MAGNONI, M. S.; MAIA, L.; LISTONI,A. J.; HECKLER, M. C.; SUDANO, M. J.; GOLIM, M. A.; LANDIM-ALVARENGA, F. D.; AMORIM, R. M. Equine mesenchymal stem cells from bone marrow, adipose tissue and umbilical cord: immunophenotypic characterization and differentiation potential. Stem Cell Research \& Therapy, London, v. 5, n. 1, p. 1-11, 2014

BECERRA, P.; VALDES VAZQUEZ, M. A.; DUDHIA, J.; FISKE-JACKSON, A. R.; NEVES, F.; HARTMAN, N. G.; SMITH, R. K. Distribution of injected technetium(99m)-labeled mesenchymal stem cells in horses with naturally occurring tendinopathy. Journal of Orthopaedic Research, Oxford, v. 31, n. 7, p. 1096-1102, 2013.

BOSCH, G.; MOLEMAN, M.; BARNEVELD, A.; VAN WEEREN, P. R.; VAN SCHIE, H. T. The effect of platelet-rich plasma on the neovascularization of surgically created equine superficial digital flexor tendon lesions. Scandinavian Journal of Medicine Science Sports, Copenhague, v. 21, n. 4, p. 554-561, 2011. 
BOSCH, G.; VAN SCHIE, H. T.; DE GROOT, M. W.; CADBY, J. A.; VAN DE LEST, C. H.; BARNEVELD, A.; VAN WEEREN, P. R. Effects of platelet-rich plasma on the quality of repair of mechanically induced core lesions in equine superficial digital flexor tendons: A placebocontrolled experimental study. Journal of Orthopaedic Research, Oxford, v. 28, n. 2, p. 211-217, 2010.

BURK, J.; GITTEL, C.; HELLER, S.; PFEIFFER, B.; PAEBST, F.; AHRBERG, A.B.; BREHM, W. Gene expression of tendon markers in mesenchymal stromal cells derived from different sources. BMC Research Notes, London, v. 7, n. 1, p. 1-6, 2014.

BUTLER, D. L.; JUNCOSA-MELVIN, N.; BOIVIN, G. P.; GALLOWAY, M. T.; SHEARN, J. T.; GOOCH, C.; AWAD, H. Functional tissue engineering for tendon repair: a multidisciplinary strategy using mesenchymal stem cells, bioscaffolds, and mechanical stimulation. Journal of Orthopaedic Research, Oxford, v. 26, n. 1, p. $1-9,2008$.

CAPLAN, A. I. Why are MSCs therapeutic? New data: new insight. The Journal of Pathology: Clinical Research, Malden, v. 217, n. 2, p. 318-324, 2009.

CAPLAN, A. I.; DENNIS, J. E. Mesenchymal stem cells as trophic mediators. Journal of Cell Biochemistry, Malden, v. 98, n. 5, p. 1076-1084, 2006.

CARTER-ARNOLD, J. L.; NEILSEN, N. L.; AMELSE, L. L.; ODOI, A.; DHAR, M. S. In vitro analysis of equine, bone marrow-derived mesenchymal stem cells demonstrates differences within age- and gendermatched horses. Equine Veterinary Journal, Ely, v. 46, n. 5, p. 589-595, 2014.

CARVALHO, A. M.; ALVAREZ, L. E. C.; OLIVEIRA, P. G. G.; VENDRUSCOLO, C. P.; MOROZ, A.; DEFFUNE, E.; HUSSNI, C. A.; ALVES, A. L. G. Use of power doppler for the assessment of vascularization in equine tendinitis treated with mesenchymal stem cells. Journal of Animal and Veterinary Advances, Faisalabad, v. 13, n. 1, p. 15-20, 2014a.

CARVAlHO, A. M.; ALVES, A. L. G.; GOliM, M. A.; MOROZ, A.; HUSSNI, C. A.; OLIVEIRA, P. G. G. de; DEFFUNE, E. Isolation and immunophenotypic characterization of mesenchymal stem cells derived from equine species adipose tissue. Veterinary Immunology and Immunopathology, Amsterdam, v. 132, n. 2-4, p. 303-306, 2009.

CARVAlHO, A. M.; ALVES, A. L. G.; OLIVEIRA, P. G. G. de; CISNEROS ÁlVAREZ, L. E.; AMORIM, R. L.; HUSSNI, C. A.; DEFFUNE, E. Use of adipose tissue-derived mesenchymal stem cells for experimental tendinitis therapy in equines. Journal of Equine
Veterinary Science, New York, v. 31, n. 1, p. 26-34, 2011.

CARVALHO, A. M.; BADIAL, P. R.; ALVAREZ, L. E.; YAMADA, A. L.; BORGES, A. S.; DEFFUNE, E.; HUSSNI, C. A.; GARCIA ALVES, A. L. Equine tendonitis therapy using mesenchymal stem cells and platelet concentrates: a randomized controlled trial. Stem Cell Research and Therapy, London, v. 4, n. 4, p. 1-13, 2013a.

CARVALHO, A. M.; YAMADA, A. L. M.; GOLIM, M. A.; ALVAREZ, L. E. C.; HUSSNI, C. A.; ALVES, A. L. Evaluation of mesenchymal stem cell migration after equine tendonitis therapy. Equine Veterinary Journal, Ely, v. 46, n. 5, p. 635-638, 2014b.

CARVALHO, A. M.; YAMADA, A. L. M.; GOLIM, M. A.; ÁLVAREZ, L. E. C.; JORGE, L. L.; CONCEIÇÃO, M. L.; DEFFUNE, E.; HUSSNI, C. A.; ALVES, A. L. G. Characterization of mesenchymal stem cells derived from equine adipose tissue. Arquivo Brasileiro de Medicina Veterinária e Zootecnia, Belo Horizonte, v. 65, n. 4, p. $939-945,2013$ b.

CONZE, P.; VAN SCHIE, H. T.; VAN WEEREN, R.; STASZYK, C.; CONRAD, S.; SKUTELLA, T.; HOPSTER, K.; ROHN, K.; STADLER, P.; GEBUREK, F. Effect of autologous adipose tissue-derived mesenchymal stem cells on neovascularization of artificial equine tendon lesions. Regenerative Medicine, London, v. 9, n. 6, p. 743-757, 2014.

DE SCHAUWER, C.; GOOSSENS, K.; PIEPERS, S.; HOOGEWIJS, M. K.; GOVAERE, J. L.; SMITS, K.; MEYER, E.; VAN SOOM, A.; VAN DE WALLE, G. R. Characterization and profiling of immunomodulatory genes of equine mesenchymal stromal cells from noninvasive sources. Stem Cell Research and Therapy, London, v. 5, n. 1, p. 1-13, 2014.

DE SCHAUWER, C.; MEYER, E.; VAN DE WALLE, G. R.; VAN SOOM, A. Markers of stemness in equine mesenchymal stem cells: a plea for uniformity. Theriogenology, Philadelphia, v. 75, n. 8, p. 1431-1443, 2011.

DEL BUE, M.; RICCO, S.; RAMONI, R.; CONTI, V.; GNUDI, G.; GROLLI, S. Equine adipose-tissue derived mesenchymal stem cells and platelet concentrates: their association in vitro and in vivo. Veterinary Research Communication, Midlothian, v. 32, p. S51-55, 2008. Supplement 1.

DURANDO, M. M.; ZARUCCO, L.; SCHAER, T. P.; ROSS, M.; REEF, V. B. Pneumopericardium in a horse secondary to sternal bone marrow aspiration. Equine Veterinary Education, Ely, v. 18, n. 2, p. 75-79, 2006. 
FORTIER, L. A.; SMITH, R. K. Regenerative medicine for tendinous and ligamentous injuries of sport horses. Veterinary Clinics of North America: Equine Practice, Fort Collins, v. 24, n. 1, p. 191-201, 2008.

GARVICAN, E. R.; DUDHIA, J.; ALVES, A. L.; CLEMENTS, L. E.; PLESSIS, F. D.; SMITH, R. K. Mesenchymal stem cells modulate release of matrix proteins from tendon surfaces in vitro: a potential beneficial therapeutic effect. Regenerative Medicine, London, v. 9, n. 3, p. 295-308, 2014.

GIMBLE, J. M.; GUILAK, F.; BUNNELL, B. A. Clinical and preclinical translation of cell-based therapies using adipose tissue-derived cells. Stem Cell Research and Therapy, London, v. 1, n. 2, p. 1-8, 2010.

GODWIN, E. E.; YOUNG, N. J.; DUDHIA, J.; BEAMISH, I. C.; SMITH, R. K. Implantation of bone marrow-derived mesenchymal stem cells demonstrates improved outcome in horses with overstrain injury of the superficial digital flexor tendon. Equine Veterinary Journal, Ely, v. 44, n. 1, p. 25-32, 2012.

GONÇALVES, A. I.; RODRIGUES, M. T.; LEE, S. J.; ATALA, A.; YOO, J. J.; REIS, R. L.; GOMES, M. E. Understanding the role of growth factors in modulating stem cell tenogenesis. PLoS One, San Francisco, v. 8, n. 12, p. 1-10, 2013.

GUERCIO, A.; DI MARCO, P.; CASELLA, S.; RUSSOTTO, L.; PUGLISI, F.; MAJOLINO, C.; GIUDICE, E.; DI BELLA, S.; PURPARI, G.; CANNELLA, V.; PICCIONE, G. Mesenchymal stem cells derived from subcutaneous fat and platelet-rich plasma used in athletic horses with lameness of the superficial digital flexor tendon. Journal of Equine Veterinary Science, New York, v. 35, n. 1, p. 19-26, 2015.

GUEST, D. J.; SMITH, M. R.; ALLEN, W. R. Monitoring the fate of autologous and allogeneic mesenchymal progenitor cells injected into the superficial digital flexor tendon of horses: preliminary study. Equine Veterinary Journal, Ely, v. 40, n. 2, p. 178-181, 2008.

IZADPANAH, R.; TRYGG, C.; PATEL, B.; KRIEDT, C.; DUfOUR, J.; GIMBLE, J. M.; BUNNELL, B. A. Biologic properties of mesenchymal stem cells derived from bone marrow and adipose tissue. Journal of Cellular Biochemistry, Malden, v. 99, n. 5, p. 1285-1297, 2006.

KASASHIMA, Y.; TAKAHASHI, T.; SMITH, R. K.; GOODSHIP, A. E.; KUWANO, A.; UENO, T.; HIRANO, S. Prevalence of superficial digital flexor tendonitis and suspensory desmitis in Japanese Thoroughbred flat racehorses in 1999. Equine Veterinary Journal, Ely, v. 36, n. 4, p. 346-350, 2004.
LANGE-CONSIGLIO, A.; CORRADETTI, B.; BIZZARO, D.; MAGATTI, M.; RESSEL, L.; TASSAN, S.; PAROLINI, O.; CREMONESI, F. Characterization and potential applications of progenitor-like cells isolated from horse amniotic membrane. Journal of Tissue Engineering and Regenerative Medicine, TaipasGuimarães, v. 6, n. 8, p. 622-635, 2012.

LOPEZ, M. J.; JARAZO, J. State of the art: stem cells in equine regenerative medicine. Equine Veterinary Journal, Ely, v. 47, n. 2, p. 145-154, 2015.

LUI, P. P.; MAFFULLI, N.; ROLF, C.; SMITH, R. K. What are the validated animal models for tendinopathy? Scandinavian Journal of Medicine Science Sports, Copenhague, v. 21, n. 1, p. 3-17, 2011.

MAMBELLI, L. I.; SANTOS, E. J.; FRAZAO, P. J.; CHAPARRO, M. B.; KERKIS, A.; ZOPPA, A. L.; KERKIS, I. Characterization of equine adipose tissuederived progenitor cells before and after cryopreservation. Tissue Engineering Part C: Methods, New Rochelle, v. 15, n. 1, p. 87-94, 2009.

MARFE, G.; ROTTA, G.; DE MARTINO, L.; TAFANI, M.; FIORITO, F.; DI STEFANO, C.; POLETTINI, M.; RANALLI, M.; RUSSO, M. A.; GAMBACURTA, A. A new clinical approach: use of blood-derived stem cells (BDSCs) for superficial digital flexor tendon injuries in horses. Life Sciences, Columbus, v. 90, n. 21-22, p. 825830, 2012.

MCCULlAGH, K. G.; GOODSHIP, A. E.; SILVER, I. A. Tendon injuries and their treatment in the horse. Veterinary Record, London, v. 105, n. 3, p. 54-57, 1979.

MERCATI, F.; PASCUCCI, L.; CURINA, G.; SCOCCO, P.; TARDELLA, F. M.; DALL'AGLIO, C.; MARINI, C.; CECCARELLI, P. Evaluation of storage conditions on equine adipose tissue-derived multipotent mesenchymal stromal cells. Veterinary Journal, Ely, v. 200, n. 2, p. 339-342, 2014.

MUTTINI, A.; SALINI, V.; VALBONETTI, L.; ABATE, M. Stem cell therapy of tendinopathies: suggestions from veterinary medicine. Muscles Ligaments Tendons Journal, Roma, v. 2, n. 3, p. 187-192, 2012.

NIXON, A. J.; DAHLGREN, L. A.; HAUPT, J. L.; YEAGER, A. E.; WARD, D. L. Effect of adipose-derived nucleated cell fractions on tendon repair in horses with collagenase-induced tendinitis. American Journal of Veterinary Research, Schaumburg, v. 69, n. 7, p. 928937, 2008.

NIXON, A. J.; WATTS, A. E.; SCHNABEL, L. V. Celland gene-based approaches to tendon regeneration. Journal of Shoulder and Elbow Surgery, Philadelphia, v. 21, n. 2, p. 278-294, 2012. 
NOTH, U.; RACKWITZ, L.; STEINERT, A. F.; TUAN, R. S. Cell delivery therapeutics for musculoskeletal regeneration. Advanced Drug Delivery Reviews, Salt Lake City, v. 62, n. 7-8, p. 765-783, 2010.

PROCKOP, D. J.; OH, J. Y. Mesenchymal stem/stromal cells (MSCs): role as guardians of inflammation. Molecular Therapy, New York, v. 20, n. 1, p. 14-20, 2012.

RAABE, O.; SHELL, K.; FIETZ, D.; FREITAG, C.; OHRNDORF, A.; CHRIST, H. J.; WENISCH, S.; ARNHOLD, S. Tenogenic differentiation of equine adipose-tissue-derived stem cells under the influence of tensile strain, growth differentiation factors and various oxygen tensions. Cell and Tissue Research, London, v. 352, n. 3, p. 509-521, 2013.

REED, S. A.; LEAHY, E. R. Growth and development symposium: stem cell therapy in equine tendon injury. Journal of Animal Science, Champaign, v. 91, n. 1, p. 59-65, 2013.

RICCO, S.; RENZI, S.; DEL BUE, M.; CONTI, V.; MERLI, E.; RAMONI, R.; LUCARELLI, E.; GNUDI, G.; FERRARI, M.; GROLLI, S. Allogeneic adipose tissue-derived mesenchymal stem cells in combination with platelet rich plasma are safe and effective in the therapy of superficial digital flexor tendonitis in the horse. International Journal of Immunopathology and Pharmacology, Chieti, v. 26, n. 1, p. 61-68, 2013. Supplement.

SCHNABEL, L. V.; FORTIER, L. A.; MCILWRAITH, C. W.; NOBERT, K. M. Therapeutic use of stem cells in horses: which type, how, and when? Veterinary Journal, Ely, v. 197, n. 3, p. 570-577, 2013.

SCHNABEL, L. V.; PEZZANITE, L. M.; ANTCZAK, D. F.; FELIPPE, M. J.; FORTIER, L. A. Equine bone marrow-derived mesenchymal stromal cells are heterogeneous in MHC class II expression and capable of inciting an immune response in vitro. Stem Cell Research and Therapy, London, v. 5, n. 1, p. 1-13, 2014.

SMITH, R. K.; KORDA, M.; BLUNN, G. W.; GOODSHIP, A. E. Isolation and implantation of autologous equine mesenchymal stem cells from bone marrow into the superficial digital flexor tendon as a potential novel treatment. Equine Veterinary Journal, Ely, v. 35, n. 1, p. 99-102, 2003.

SMITH, R. K.; WEBBON, P. M. Harnessing the stem cell for the treatment of tendon injuries: heralding a new dawn? British Journal of Sports Medicine, London, v. 39, n. 9, p. 582-584, 2005.
SMITH, R. K.; WERLING, N. J.; DAKIN, S. G.; ALAM, R.; GOODSHIP, A. E.; DUDHIA, J. Beneficial effects of autologous bone marrow-derived mesenchymal stem cells in naturally occurring tendinopathy. PLoS One, San Francisco, v. 8, n. 9, p. 1-14, 2013.

SPAAS, J. H.; GUEST, D. J.; VAN DE WALLE, G. $\mathrm{R}$. Tendon regeneration in human and equine athletes: UbiSumus-Quo Vadimus (where are we and where are we going to)? Sports Medicine, Auckland, v. 42, n. 10, p. 871-890, 2012.

STRIOGA, M.; VISWANATHAN, S.; DARINSKAS, A.; SLABY, O.; MICHALEK, J. Same or not the same?Comparison of adipose tissue-derived versus bone marrow-derived mesenchymal stem and stromal cells. Stem Cells Development, Detroit, v. 21, n. 14, p. 27242752, 2012.

TEXTOR, J. A.; TABLIN, F. Activation of equine plateletrich plasma: comparison of methods and characterization of equine autologous thrombin. Veterinary Surgery, Davis, v. 41, n. 7, p. 784-794, 2012.

UYSAL, C. A.; TOBITA, M.; HYAKUSOKU, H.; MIZUNO, H. Adipose-derived stem cells enhance primary tendon repair: biomechanical and immunohistochemical evaluation. Journal of Plastic, Reconstructive \& Aesthetic Surgery, Kidlington, v. 65, n. 12, p. 1712-1719, 2012.

VAN LOON, V. J.; SCHEFFER, C. J.; GENN, H. J.; HOOGENDOORN, A. C.; GREVE, J. W. Clinical followup of horses treated with allogeneic equine mesenchymal stem cells derived from umbilical cord blood for different tendon and ligament disorders. Veterinary Quarterly, Amsterdan, v. 34, n. 2, p. 92-97, 2014.

VAN, R. L.; BAYLISS, C. E.; RONCARI, D. A. Cytological and enzymological characterization of adult human adipocyte precursors in culture. The Journal of Clinical Investigation, Michigan, v. 58, n. 3, p. 699-704, 1976.

VIDAL, M. A.; KILROY, G. E.; LOPEZ, M. J.; JOHNSON, J. R.; MOORE, R. M.; GIMBLE, J. M. Characterization of equine adipose tissue-derived stromal cells: adipogenic and osteogenic capacity and comparison with bone marrow-derived mesenchymal stromal cells. Veterinary Surgery, Davis, v. 36, n. 7, p. 613-622, 2007.

WANG, M.; CRISOSTOMO, P. R.; HERRING, C.; MELDRUM, K. K.; MELDRUM, D. R. Human progenitor cells from bone marrow or adipose tissue produce VEGF, HGF, and IGF-I in response to TNF by a p38 MAPK-dependent mechanism. American Journal of Physiology. Regulatory, Integrative and Comparative Physiology, Bethesda, v. 291, n. 4, p. R880-884, 2006. 
WATTS, A. E. Use of stem cells in equine musculoskeletal disorders. Equine Veterinary Education, Ely, v. 26, n. 9, p. 492-498, 2014.

WILLIAMS, I. F.; HEATON, A.; MCCULLAGH, K. G. Cell morphology and collagen types in equine tendon scar. Research in Veterinary Science, Rome, v. 28, n. 3, p. 302-310, 1980.
YOUNG, M. Stem cell applications in tendon disorders: a clinical perspective. Stem Cells International, New York, v. 2012, n. 1, p. 1-10, 2012.

ZUK, P. A.; ZHU, M.; MIZUNO, H.; HUANG, J.; FUTRELL, J. W.; KATZ, A. J.; BENHAIM, P.; LORENZ, H. P.; HEDRICK, M. H. Multilineage cells from human adipose tissue: implications for cell-based therapies. Tissue Engineering, New Rochelle, v. 7, n. 2, p. 211-228, 2001. 